\title{
Treatments for Sclerotinia sclerotiorum on Inoculated Bean Seeds and Effects on Health and Physiological Quality
}

\author{
Brenda Tortelli
}

Plant Pathology Laboratory, Federal University of Fronteira Sul - Campus Erechim ERS 135 - Km 72, No 200, PO Box 764, Zip Code: 99700-970, Erechim - RS, Brazil E-mail: bre.tortelli@ hotmail.com

\begin{abstract}
Suelen Cappellaro
Plant Pathology Laboratory, Federal University of Fronteira - Campus Erechim ERS 135 - Km 72, No 200, PO Box 764, Zip Code: 99700-970, Erechim - RS, Brazil PRO-ICT/UFFS Scholarship

E-mail: suelen02cappellaro@hotmail.com
\end{abstract}

Júlia Andrade

Plant Pathology Laboratory, Federal University of Fronteira Sul - Campus Erechim ERS 135 - Km 72, № 200, PO Box 764, Zip Code: 99700-970, Erechim - RS, Brazil UFFS - Academic Monitoring Scholarship E-mail: julia_andrade09@hotmail.com

\section{Márcio Paulo Mezzomo}

Plant Pathology Laboratory, Federal University of Fronteira Sul - Campus Erechim ERS 135 - Km 72, № 200, PO Box 764, Zip Code: 99700-970, Erechim - RS, Brazil E-mail: marciopaulo.mezomo@gmail.com

Péricles Roberto Steffen

Plant Pathology Laboratory, Federal University of Fronteira Sul - Campus Erechim 
ERS 135 - Km 72, No 200, PO Box 764, Zip Code: 99700-970, Erechim - RS, Brazil

E-mail: periclessteffenagro2015@gmail.com

\author{
Vanessa Neumann Silva \\ Seed and Grain Laboratory, Federal University of Fronteira Sul - Campus Chapecó \\ Rodovia SC 484 - Km 02, Fronteira Sul, Zip Code: 89815-899, Chapecó - SC, Brazil \\ E-mail: vanessa.neumann@uffs.edu.br
}

\begin{abstract}
Paola Mendes Milanesi (Corresponding author)
Plant Pathology Laboratory, Federal University of Fronteira Sul - Campus Erechim

ERS 135 - Km 72, Nº 200, PO Box 764, Zip Code: 99700-970, Erechim - RS, Brazil

Tel: 55-54-3321-7336_E-mail: paola.milanesi@uffs.edu.br
\end{abstract}

Received: Jan. 11, 2020

Accepted: Feb. 9, 2020

Published: Feb. 25, 2020

doi:10.5296/jas.v8i1.16207

URL: https://doi.org/10.5296/jas.v8i1.16207

\begin{abstract}
Considering the importance of bean cultivation, the objective was to prove the effectiveness of the seed microbiolization method in the control of Sclerotinia sclerotiorum $(S s)$ on black bean seeds (cv. IPR Tuiuiú), inoculated by the water restriction method. The treatments were fungicide methyl thiophanate + fluazinam $\left(350.0 \mathrm{~g} \mathrm{~L}^{-1}+52.5 \mathrm{~g} \mathrm{~L}^{-1}\right)$; Trichoderma asperellum BV-10 (1.0 x $10^{10}$ conidia mL $\left.\mathrm{m}^{-1}\right)$; T. harzianum strain CCT $7589\left(1 \times 10^{9} \mathrm{CFUs} \mathrm{L}^{-1}\right)$; Bacillus

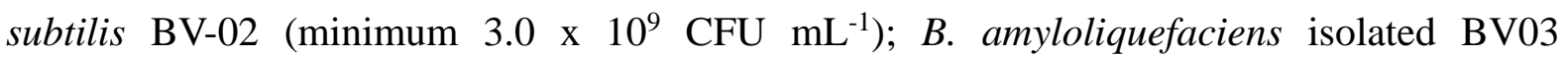
(minimum $3.0 \times 10^{9} \mathrm{CFU} \mathrm{L}^{-1}$ ); Positive control (seeds exposed to $\mathrm{Ss}$ ); fungicide; $T$. asperellum BV-10; T. harzianum strain CCT 7589; B. subtilis BV-02; B. amyloliquefaciens isolate BV03; and Negative control (PDA medium plus restricting). The effects of these treatments on germination, vigor, and the health of bean seeds, and seedling emergence in the field, were evaluated. Microbiolization with T. asperellum and T. harzianum, provides improvement in germination, vigor, and health, but is not superior to fungicide treatment. Bacillus subtilis and B. amyloliquefaciens, in seeds not inoculated with the pathogen, produce the best results for fresh and dry mass $(\mathrm{g})$. These may be used in the integrated management of white bean mold.
\end{abstract}

Keywords: white mold, Phaseolus vulgaris L., water restriction, microbiolization 


\section{Introduction}

The bean (Phaseolus vulgaris L.) is a legume of great economic and social importance in Brazil as it is a source of income for many family farmers, who depend on bean production and also because it is part of the population's diet (Binotti et al., 2009). In 2019, the first crop season of beans reached a production of 973.7 thousand tons and, by the end of the third crop, it is estimated to reach 3.1 million tons (Conab, 2019).

However, several factors can affect bean production capacity; one of these is disease incidence. Diseases affecting bean crops include white mold, caused by Sclerotinia sclerotiorum (Ascomycota; Sclerotiniaceae family) (Mycobank, 2019), which is considered one of the main and most destructive bean diseases (Wendland et al., 2016). White mold can cause $100 \%$ yield losses in crops with high severity of the disease, that is spread from infected seeds, where the pathogen survives for long periods, increasing the source of inoculum at each seeding with the same host (Wu and Subbarao, 2008).

Thus, the treatment of seeds with fungicides is an important procedure in bean production, since they are efficient in controlling the pathogens associated with seeds and also with soil (Machado, 2000). When performed effectively and in quality seeds, the treatment ensures an adequate initial stand (Tonello et al., 2019). The integration of white mold management measures provides, in addition to crop rotation, the application of fungicides with different active ingredients, including multisites, preventing or delaying the emergence of fungicide-resistant S. sclerotiorum populations (Lehner et al., 2017).

The search for disease control methods that are not considered only in chemical control has intensified in recent years. In this context, the use of biological control agents is one of the alternatives for seed treatment, aiming at greater sustainability in agriculture (Xu et al., 2011). The fungi Trichoderma harzianum (Zhang et al., 2016) and T. asperellum (Kipngeno et al., 2015), as well as the bacteria Bacillus subtilis (Wang et al., 2018) and B. amyloliquefasciens (El-Gremi et al., 2017), have been successfully used in the microbiolization of seeds of various agricultural crops. This is a safe method that does not cause environmental imbalance, allowing subsequent sowing with minor disease-related problems. These microorganisms can also act as biostimulants, promoting plant growth (Harman, 2006; Moura et al., 2018).

In order to enable seed inoculation with a pathogen and subsequent treatment (chemical and biological), there are methods that guarantee the reproduction and expression of symptoms and signs typical of a particular seed-associated plant pathology. Therefore, it is essential that such methods enable seed infection but without compromising germination potential and seedling emergence (Rocha et al., 2014), to allow future evaluation. The most used seed inoculation methods involve immersion of the seeds in a spore suspension (Pedroso et al., 2010); direct contact between the seeds and the fungal culture developed in culture medium (Migliorini et al., 2018); and osmotic conditioning, with the use of water restriction (Venturoso et al., 2015).

In this context, the objective of this study was to evaluate the effect of chemical and biological treatment on germination, vigor and the health of bean seeds (cv. IPR Tuiuiú) inoculated with Sclerotinia sclerotiorum by water restriction. 


\section{Material and Methods}

The experiment was carried out in Erechim - Rio Grande do Sul (RS), Brazil (27 $37^{\prime} 50^{\prime \prime} \mathrm{S}$, $52^{\circ} 14^{\prime} 11^{\prime \prime} \mathrm{W}$, altitude: $753 \mathrm{~m}$ ), in a completely randomized design with four replications. Bean seeds of cultivar IPR Tuiuiú (black group, medium cycle: 88 days), 2019 crop, classification $\mathrm{C} 1$, were used. The seeds had the following characteristics: $i$ ) humidity: 15\%, this is above the recommended value of $13 \%$ (Zucareli et al., 2015); ii) electrical conductivity: $54,35 \mu \mathrm{S} \mathrm{cm}^{-1} \mathrm{~g}^{-1}$, considered of high vigor (Smaniotto et al., 2013); iii) germination: $96 \%$, above the minimum standard required in Brazil for commercialization, which is $80 \%$ (Brasil, 2013); and iv) health, storage fungi only: Rhizopus spp. (14\%), Aspergillus spp. (5\%), and Penicillium spp. (17\%).

The inoculum of Sclerotinia sclerotiorum was obtained from pathogen sclerotia collected from soybean plants with symptoms of white mold in a field located in Erechim (RS). The sclerotia were submitted to asepsis with $1 \%$ sodium hypochlorite for $1 \mathrm{~min}$ and sterile distilled water (three rinses of $1 \mathrm{~min}$ each). In Petri dishes containing potato-dextrose-agar (PDA) culture medium, the sclerotia were distributed, and then the plates were incubated at $23{ }^{\circ} \mathrm{C}$ with a 12-hour photoperiod (Pereira et al., 2009). After 7 days of incubation, the pathogen structures were subcultured onto plates containing PDA culture medium to obtain the pure culture.

Through the water restriction technique (Coutinho et al., 2001; Cruciol and Costa, 2017), the pathogen was cultivated on PDA culture medium supplemented with the osmotic restrictor mannitol $\left(\mathrm{C}_{6} \mathrm{H}_{14} \mathrm{O}_{6}\right)$ in order to guarantee a water potential of $-0.6 \mathrm{MPa}\left(44.88 \mathrm{~g}\right.$ of mannitol L $\mathrm{L}^{-1}$ PDA) (Coutinho et al., 2001). Plates were incubated at $23{ }^{\circ} \mathrm{C}$ with a 12 -hour photoperiod for 7 days when mycelial growth of $S$. sclerotiorum reached the edges of the petri dish. The bean seeds were distributed on the PDA + mannitol medium in a single layer and then incubated at $23{ }^{\circ} \mathrm{C}$ with a photoperiod of 12 hours, remaining on the medium in direct contact with the pathogen with different exposure times $(2,6,12,18,24,36$, and 48 hours).

After this initial test, the previous procedure was repeated with 12 hours of exposure to the pathogen $\left(23{ }^{\circ} \mathrm{C}\right.$ and a photoperiod of 12 hours), due to the infection and maintenance of germination and seed vigor. These were removed from the culture medium and kept at room temperature, properly covered with sterile paper towels, to dry for 24 hours (Cruciol and Costa 2017).

Inoculated bean seeds were submitted to the following treatments:

$\mathrm{T} 1$ - fungicide methyl thiophanate + fluazinam $\left(350.0 \mathrm{~g} \mathrm{~L}^{-1}+52.5 \mathrm{~g} \mathrm{~L}^{-1} ; 180 \mathrm{~mL} / 100 \mathrm{~kg}\right.$ of seeds);

T2 - Trichoderma asperellum BV-10 (1.0 x $10^{10}$ viable conidia $\left.\mathrm{mL}^{-1} ; 200 \mathrm{~g} \mathrm{~L}^{-1} ; 1 \mathrm{~mL} / \mathrm{kg}\right)$;

T3 - Trichoderma harzianum strain CCT 7589 (1 x 109 CFUs/L; $5 \mathrm{~g} \mathrm{~L}^{-1} ; 2 \mathrm{~mL} / \mathrm{kg}$ );

T4 - Bacillus subtilis BV-02 (minimum 3.0 x 109 CFU/mL; $42 \mathrm{~g} \mathrm{~L}^{-1} ; 2 \mathrm{~mL} / \mathrm{kg}$ );

T5 - Bacillus amyloliquefaciens isolate BV03 (minimum 3.0 x 109 CFU/L; $42 \mathrm{~g} \mathrm{~L}^{-1} ; 2 \mathrm{~mL} / \mathrm{kg}$ ); T6 - Positive control (seeds exposed to the pathogen only); 
T7 - Fungicide methyl thiophanate + fluazinam;

T8 - Trichoderma asperellum BV-10;

T9 - Trichoderma harzianum strain CCT 7589;

T10 - Bacillus subtilis BV-02;

T11 - Bacillus amyloliquefaciens isolate BV03; and

T12 - Negative Control (PDA medium supplemented with mannitol only).

The seeds remained at room temperature for 24 hours for complete drying.

In order to verify the efficiency of treatments on the physiological quality of bean seeds, after exposure to Sclerotinia sclerotiorum, the following tests were performed:

Sanitation: from eight repetitions of 25 seeds, according to the methodology from the Manual for Sanitary Analysis of Seeds (Brasil 2009a). Using the freeze-free blotter test method, the seeds were distributed among gerbox boxes $(11.0 \times 11.0 \times 3.0 \mathrm{~cm})$ containing two sheets of blotter paper. In order to suppress seed germination, the paper was moistened with 2,4-D salt solution $(5 \mathrm{ppm})$. The seeds were incubated at $20 \pm 2{ }^{\circ} \mathrm{C}$ with a photoperiod of 12 hours for 7 days and analyzed with the aid of stereoscopic and optical microscopes. The percentage $(\%)$ of fungal incidence, identified according to specialized literature (Barnett and Hunter, 1999; Brasil, 2009a), was determined.

Germination: the method of Seed Analysis Rules (Brasil, 2009b) was used, with four replications of 50 seeds. The seeds were placed on germitest paper moistened with distilled water at 2.5 to 3 times their dry weight. After sowing, rolls were made and placed in a germination chamber at $25 \pm 2{ }^{\circ} \mathrm{C}$, with a photoperiod of 12 hours. The evaluations occurred by counting at five and nine days after sowing (DAS). In the first count, all germinated seeds that originated normal seedlings were counted. At the second count, the seedlings were classified as normal, abnormal, and non-germinated seeds (hard and dead).

Germination speed index (GSI): performed from eight repetitions of 25 seeds each, distributed on sterile moistened germitest paper. The samples were incubated at $25 \pm 2{ }^{\circ} \mathrm{C}$ with a photoperiod of 12 hours. Germinated seeds were evaluated daily by counting normal seedlings until the fifth day, together with the first twinning count (Brasil, 2009b). After obtaining daily data on the number of normal plants, the GSI was calculated (Maguire, 1962).

Cold without soil: conducted in a similar way to the germination test, the seed-containing rolls remained in an incubator at $10 \pm 2{ }^{\circ} \mathrm{C}$, with no photoperiod, for three days (Miguel and Cicero, 1999; Guiscem et al., 2010). Thereafter, the rolls were placed in an incubator at $25 \pm 2{ }^{\circ} \mathrm{C}$ with a 12-hour photoperiod for four days, and the usual seedling counts were performed (Brasil, 2009b).

Accelerated aging: four samples of 50 seeds for each treatment were distributed on aluminum screens, suspended in gerbox, containing $40 \mathrm{~mL}$ of distilled water, and kept in an incubator for 72 hours at $42 \pm 2{ }^{\circ} \mathrm{C}$. Soon after, the germination test was assembled, performing the first and 
second count of germinated seeds, as previously described in the bean germination test (Marcos Filho, 1999).

Field emergence: four replications with 50 seeds were used, and emergence evaluation was performed at 30 days after sowing (DAS), accounting for the number of emerged plants, that is, plants that had fully expanded primary leaflets (Migliorini et al., 2017). At 30 DAS the plants present in each plot were collected to quantify plant fresh and dry mass (g). For this, 25 plants were removed from each repetition and placed in kraft paper bags (capacity $3 \mathrm{~kg}$ ). The samples were placed in a drying oven with forced air circulation at $65^{\circ} \mathrm{C}$ until they reached a constant weight, and the values were expressed in $\mathrm{g}^{\text {seedling }}{ }^{-1}$ (Dutra et al., 2012).

Statistical analysis: the data obtained were submitted to analysis of variance by the F test $(\mathrm{p} \leq$ $0.05)$ and, when significant, the means were compared by the Tukey test $(p \leq 0.05)$. The analyses were performed using the statistical software SISVAR version 5.6 (Ferreira, 2011).

\section{Results and Discussion}

The inoculation of Sclerotinia sclerotiorum in bean seeds by the water restriction method was efficient and reached up to $100 \%$ colonization when the seeds were left in direct contact with the pathogen for 48 hours (Figure 1). In this study, we opted for 12 hours of exposure to the pathogen, which resulted in a colonization rate of $50 \%$ of the seeds, allowing the evaluation of germination and vigor. This behavior corroborates what has already been observed for Colletotrichum lindemuthianum vs. beans (Migliorini et al., 2017) and also for S. sclerotiorum $v s$. beans, in which there was a reduction of over $60 \%$ in seedling emergence in infected seeds (Venturoso et al., 2015).

Seeds that were not inoculated with Sclerotinia sclerotiorum showed the best performance in the analyzed variables and no incidence of the fungus (Table 1). These results demonstrate the importance of the use of quality seeds to obtain an adequate crop establishment in the field (Araujo et al., 2011). However, the higher the initial inoculum level of a given pathogen, the higher the percentage of dead seeds (Rey et al., 2009).

Of the treatments that were inoculated, only fungicide-treated seeds did not differ statistically from those that were not inoculated (Table 1), indicating the efficiency of the product. The active ingredient fluazinam is also used to control white mold on crops, and according to Sumida et al. (2015), this fungicide is effective at inhibiting mycelial growth and carpogenic germination of $S$. sclerotiorum sclerotia, ensuring high efficiency in soybean disease control under field conditions. 


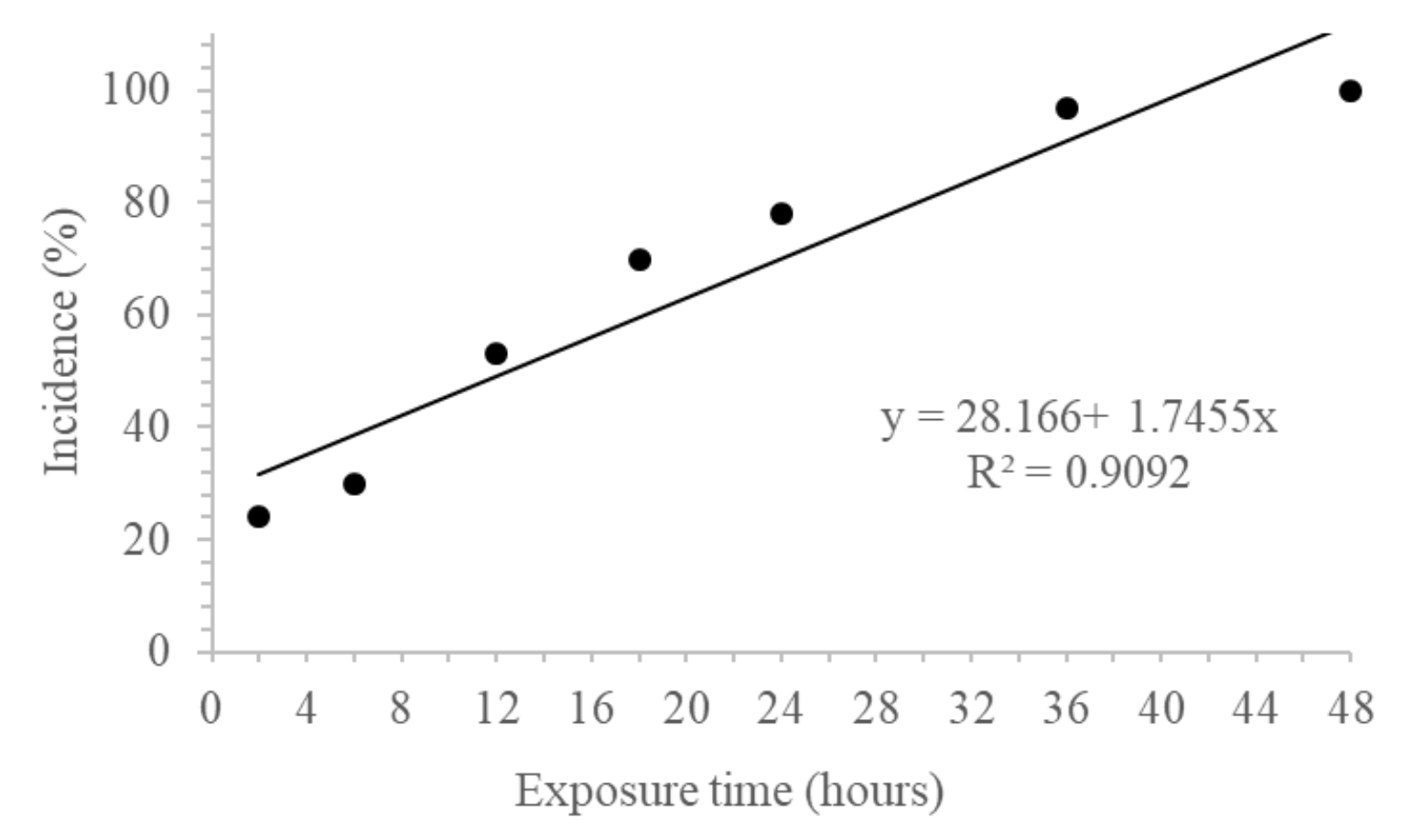

Figure 1. Incidence of Sclerotinia sclerotiorum in bean seeds, cv. IPR Tuiuiú, inoculated or not inoculated with the pathogen by the water restriction method with mannitol (-0.6 MPa), as a function of exposure time (hours)

In the T6 (Positive control) treatment, inoculation with Sclerotinia sclerotiorum caused damage to the bean seeds, as the lowest averages in all examined variables were obtained for this treatment (Table 1). Because it is the Control, where the seeds have not received any treatment, the pathogen can cause the seeds to die before they even begin the germination process, which may be related to the aggressiveness of Sclerotinia sclerotiorum, as well as conditions favorable to its establishment and rapid colonization of plant tissues by the pathogen (Venturoso et al., 2015).

Treatment with the thiophanate-methyl + fluazinam fungicide ensured that even in seeds inoculated with the pathogen, the analyzed variables achieved similar results to those of non-inoculated seeds. Figueirêdo et al. (2010) also verified efficient control of Sclerotinia sclerotiorum in the common bean after application of a fungicide with thiophanate methyl as the active ingredient.

The treatments performed with Trichoderma harzianum (T2) and T. asperellum (T3) produced superior results to the others in the inoculated seeds (T1-T6) (Table 1). Similarly, Carvalho et al. (2011) found that three T. harzianum isolates provided higher germination percentages in common bean seeds, cv. 'Jalo Precoce', which were not treated. The fact that Trichoderma species have the potential for white mold control can be attributed to the action of metabolites and parasitism exerted on S. sclerotiorum hyphae (Harman, 2006). Moreover, in plants colonized by $T$. harzianum, there was a greater ability to combat pathogenic fungal attacks 
(Zhang et al., 2017), showing that this antagonist causes a significant increase in the activation and accumulation of plant-related biomolecules (Singh et al., 2019).

Table 1. Incidence (Inc.,\%) of Sclerotinia sclerotiorum (Ss), germination (G,\%), germination speed index (GSI), accelerated aging (A.A.,\%) and cold test (C.T.,\%) in bean seeds, cv. IPR Tuiuiú, inoculated or not inoculated with the pathogen by the water restriction method with mannitol (-0.6 MPa) and subsequently treated

\begin{tabular}{|c|c|c|c|c|c|}
\hline \multirow{2}{*}{ Treatments } & Inc. & $\mathrm{G}$ & \multirow{2}{*}{ GSI } & A.A. & C.T. \\
\hline & \multicolumn{2}{|c|}{$\%$} & & \multicolumn{2}{|c|}{$\%$} \\
\hline $\begin{array}{l}\text { T1) Fungicide (methyl thiophanate }+ \\
\text { fluazinam) }+ \text { Ss }\end{array}$ & $2 a b^{*}$ & $97 \mathrm{a}$ & $8.8 \mathrm{abc}$ & $86.0 \mathrm{a}$ & $98.5 \mathrm{ab}$ \\
\hline $\begin{array}{l}\text { T2) Trichoderma asperellum BV-10 } \\
+ \text { Ss }\end{array}$ & $26 \mathrm{de}$ & $92 \mathrm{ab}$ & $7.8 \mathrm{bc}$ & $40.5 \mathrm{bc}$ & $93.5 \mathrm{ab}$ \\
\hline $\begin{array}{l}\text { T3) Trichoderma harzianum CCT } \\
7589+\text { Ss }\end{array}$ & 30 ef & $83 \mathrm{ab}$ & $7.4 \mathrm{c}$ & $48.0 \mathrm{~b}$ & $93.5 \mathrm{ab}$ \\
\hline T4) Bacillus subtilis BV-02 + Ss & $20 \mathrm{~cd}$ & $73 \mathrm{c}$ & $5.6 \mathrm{~d}$ & $48.0 \mathrm{~b}$ & $94.5 \mathrm{ab}$ \\
\hline $\begin{array}{l}\text { T5) Bacillus amyloliquefaciens } \\
\text { isolate } \mathrm{BV} 03+\mathrm{Ss}\end{array}$ & $11 \mathrm{bc}$ & $82 \mathrm{bc}$ & $5.0 \mathrm{~d}$ & $30.0 \mathrm{de}$ & $82.0 \mathrm{c}$ \\
\hline T6) Positive Control & $40 \mathrm{f}$ & $52 \mathrm{~d}$ & $4.2 \mathrm{~d}$ & $26.5 \mathrm{e}$ & $68.0 \mathrm{~d}$ \\
\hline $\begin{array}{l}\text { T7) Fungicide methyl thiophanate }+ \\
\text { fluazinam }\end{array}$ & $0 \mathrm{a}$ & $98 \mathrm{a}$ & $8.2 \mathrm{abc}$ & $89.0 \mathrm{a}$ & $100.0 \mathrm{a}$ \\
\hline T8) Trichoderma asperellum BV-10 & $0 \mathrm{a}$ & $98 \mathrm{a}$ & $9.2 \mathrm{ab}$ & $46.5 \mathrm{~b}$ & $98.5 \mathrm{ab}$ \\
\hline $\begin{array}{l}\text { T9) Trichoderma harzianum CCT } \\
7589\end{array}$ & $0 \mathrm{a}$ & $98 \mathrm{a}$ & $8.8 \mathrm{abc}$ & 38.0 cde & $92.5 \mathrm{ab}$ \\
\hline T10) Bacillus subtilis BV-02 & $0 \mathrm{a}$ & $99 \mathrm{a}$ & $9.5 \mathrm{a}$ & $41.5 \mathrm{bc}$ & $89.0 \mathrm{bc}$ \\
\hline $\begin{array}{l}\text { T11) Bacillus amyloliquefaciens } \\
\text { isolate BV03 }\end{array}$ & $0 \mathrm{a}$ & $97 \mathrm{a}$ & $8.2 \mathrm{abc}$ & 37.5 cde & $93.5 \mathrm{ab}$ \\
\hline T12) Negative Control & $0 \mathrm{a}$ & $97 \mathrm{a}$ & $7.4 \mathrm{c}$ & $31.0 \mathrm{de}$ & $90.0 \mathrm{bc}$ \\
\hline C.V. $(\%)^{* *}$ & 24.2 & 5.9 & 7.6 & 9.9 & 4.2 \\
\hline
\end{tabular}

*Means followed by the same lower-case letter in the column do not differ statistically by Tukey's test $(\mathrm{p} \leq 0.05) .{ }^{* *}$ Coefficient of variation. 
Regarding the GSI, the treatments that produced a lower germination rate were T4 (B. subtilis), T5 (B. amyloliquefasciens), and the positive control (T6) (Table 1). Fungicide (T1) and Trichoderma (T2 and T3) treatments favored rapid germination, which is important because it reduces the time required for bean establishment, providing competitive ability against weeds, which cause competition and reduced yield between 35\% and 80\% (Galon et al., 2016).

In the accelerated aging test, only fungicide treatments were superior, in seeds with and without exposure to the pathogen (Table 1). The incubation temperature of various fungal isolates, such as Fusarium sp., Penicillium sp., Graphium sp., and Trichoderma, was $30{ }^{\circ} \mathrm{C}$, and it should be noted that none of the Trichoderma species grows when the temperature is above $40{ }^{\circ} \mathrm{C}$ (Singh et al., 2014). Thus, considering that the seeds were exposed to $42{ }^{\circ} \mathrm{C}$ for 72 hours during the accelerated aging period, it can be understood why treatments with Trichoderma and Bacillus did not benefit seed vigor.

However, in the cold test, the results were similar to those of germination (Table 1). On soybean, cv. BRS 133, according to seed lot, percentages higher than or equal to those obtained in the germination test were also evidenced in the cold test (Vieira et al., 2010). This reinforces the indication that the seeds used in this work had high vigor.

In the field emergence analysis, the treatments in which the seeds were not inoculated and those treated with fungicide showed the best results at 30 days after sowing (Table 2). In soybeans, Sclerotinia sclerotiorum is a very aggressive pathogen and therefore reduces seedling emergence, in which case biological control with $T$. harzianum is not efficient (Silva et al., 2017). 
Table 2. Emergence (\%) of bean plants, cv. IPR Tuiuiú, fresh and dry mass (g), up to 30 days after sowing (DAS) of plants whose seeds were inoculated or not inoculated with Sclerotinia sclerotiorum $(\mathrm{Ss})$ by the water restriction method with mannitol (-0.6 MPa) and subsequently treated

\begin{tabular}{lccc}
\hline \multicolumn{1}{c}{ Treatments } & Emergence & Fresh mass & Dry mass \\
\cline { 2 - 4 } & $(\%)$ & \multicolumn{2}{c}{$(\mathrm{g})$} \\
\hline T1) Fungicide (methyl thiophanate + fluazinam) & $79 \mathrm{abc}$ & $3.8 \mathrm{abcd}{ }^{*}$ & $0.6 \mathrm{abc}$ \\
+ Ss & & & \\
T2) Trichoderma asperellum BV-10 + Ss & $67 \mathrm{~cd}$ & $2.8 \mathrm{bcd}$ & $0.4 \mathrm{c}$ \\
T3) Trichoderma harzianum CCT 7589+Ss & $74 \mathrm{abc}$ & $4.1 \mathrm{abc}$ & $0.5 \mathrm{abc}$ \\
T4) Bacillus subtilis BV-02 + Ss & $68 \mathrm{~cd}$ & $3.5 \mathrm{bcd}$ & $0.5 \mathrm{bc}$ \\
T5) Bacillus amyloliquefaciens isolate BV03 & $72 \mathrm{bcd}$ & $4.0 \mathrm{abcd}$ & $0.5 \mathrm{abc}$ \\
Ss & & & \\
T6) Positive Control & $57 \mathrm{~d}$ & $2.6 \mathrm{~cd}$ & $0.4 \mathrm{c}$ \\
T7) Fungicide methyl thiophanate + fluazinam & $88 \mathrm{a}$ & $3.2 \mathrm{bcd}$ & $0.5 \mathrm{bc}$ \\
T8) Trichoderma asperellum BV-10 & $79 \mathrm{abc}$ & $3.7 \mathrm{abcd}$ & $0.5 \mathrm{abc}$ \\
T9) Trichoderma harzianum CCT 7589 & $84 \mathrm{ab}$ & $3.4 \mathrm{bcd}$ & $0.5 \mathrm{bc}$ \\
T10) Bacillus subtilis BV-02 & $77 \mathrm{abc}$ & $5.1 \mathrm{a}$ & $0.7 \mathrm{ab}$ \\
T11) Bacillus amyloliquefaciens isolate BV03 & $75 \mathrm{abc}$ & $5.1 \mathrm{a}$ & $0.7 \mathrm{a}$ \\
\hline C.V. (\%) Negative Control & $2.4 \mathrm{~d}$ & $0.4 \mathrm{c}$ \\
\hline
\end{tabular}

*Means followed by the same lower-case letter in the column do not differ statistically by Tukey's test $(\mathrm{p} \leq 0.05)$. ${ }^{* *}$ Coefficient of variation.

The treatment of seeds with systemic and/or contact fungicides acts on several metabolic processes of phytopathogenic fungi (Cameron et al., 2017), inhibiting the growth of these pathogens with environmental conditions conducive to the development of a certain disease, ensuring that the seeds germinate without the interference of pathogens (Urrea et al., 2013).

Also, in this test, it was found that treatments with Bacillus, without inoculation of the pathogen in bean seeds, presented the best results for fresh and dry mass $(\mathrm{g})$. The other 
treatments did not differ statistically for these variables; however, the Control, both positive and negative, presented the worst results (Table 2). According to Araujo et al. (2005) this would be related to the fact that Bacillus spp. is a soil bacterium that produces hormones such as indole acetic acid (IAA) and indole butyric acid (IBA), secreting important enzymes for plant nutrition, mainly by facilitating nodulation.

Chowdappa et al. (2013) showed that IAA levels increased by $45 \%$ in roots of tomato seedlings inoculated with Trichoderma when compared with uninoculated plants; similarly, Zhang et al. (2017) found that soybean lateral roots increased up to $34.3 \%$ in relation to plants that were not inoculated with Trichoderma, indicating that there is induction in the production of auxins by $T$. harzianum, and this phenomenon is related to the plant growth stimulus (Medina et al., 2010). Canbolat et al. (2006) reported increased nutrient availability to plants provided by increased nodulation in corn and cotton plants when inoculated with Bacillus subtilis.

The application of biological control agents can also be increased by combination with other compounds of organic origin, increasing the population of antagonists and making the soil suppressive to phytopathogens. In this case, the use of sewage sludge biochar combined with $T$. harzianum maximizes the antagonistic effect, improving seed germination, as well as increasing the fresh and dry mass of bean plants inoculated with Macrophomina phaseolina (Araujo et al., 2019). In this context, it is noted that plants with more abundant root systems exploit a larger soil volume, improving nutritional conditions and thus providing greater tolerance to adverse conditions that can be found in the field, becoming less sensitive to possible soil and shoots pathogens.

With this study, we confirmed that the technique of water restriction provides efficient infection of bean seeds, cultivar IPR Tuiuiú, with the pathogen $S$. sclerotiorum, even when using shorter inoculation times. Furthermore, the chemical treatment with fungicide ensures the maintenance of the physiological quality of the seeds, which reflects on the germination, vigor and health of seeds inoculated with $S$. sclerotiorum in relation to the evaluated antagonists.

It is clear that the most efficient method for controlling Sclerotinia sclerotiorum in bean seeds is still the adoption of chemical treatment. However, the use of Trichoderma and Bacillus were also efficient when compared with the positive control. Therefore, in some aspects, the biological control agents evaluated in this work improved the potential establishment of seedlings and provided them with protection.

\section{Conclusion}

The integration of management measures for white mold in common beans must been consider not only chemical control, but also biological control. The use of methodologies, such as microbiolization of seeds, allows the infection by the pathogen, ensuring the manifestation of symptoms, making the observation of the effects of better or worse control for a given treatment more assertive.

Therefore, the microbiolization with both Trichoderma asperellum and Trichoderma harzianum improved germination, vigor, and health of bean seeds but is not yet superior to fungicide. Trichoderma harzianum, T. asperellum, Bacillus subtilis, and B. amyloliquefaciens 
in seeds not inoculated with Sclerotinia sclerotiorum, improvement the seed germination, vigor, and health, as well as the fresh and dry mass (g) of plants, wherein Bacillus subtilis and B. amyloliquefaciens stand out for the best results.

In view of an agricultural perspective less dependent on pesticides, the biological treatments evaluated in this study can be successfully used to control white mold in common beans, in the context of the integrated management of this disease.

\section{Acknowledgments}

The authors thanks to: Zanotto Seeds, for donation of the bean seeds used in this work; Vittia Biovalens Biotechnology and Simbiose Applied Agrotechnology, for donation of biological products; and IHARA Brazil, for donation of fungicide thiophanate-methyl + fluazinam, which made up the treatments evaluated in this work.

\section{References}

Araujo, A. S., Blum, L. E. B., \& Figueiredo, C. C. (2019). Biochar and Trichoderma harzianum for the Control of Macrophomina phaseolina. Brazilian Archives of Biology and Technology, 62, e19180259. https://doi.org/10.1590/1678-4324-2019180259

Araujo, F. F., Henning, A., \& Hungria, M. (2005). Phytohormones and antibiotics produced by Bacillus subtilis and their effects on seed pathogenic fungi and on soybean root development. World Journal of Microbiology and Biotechnology, 21(8-9), 1639-1645. https://doi.org/10.1007/s11274-005-3621-X

Araujo, R. F., Zonta, B. J., Araujo, F. E., Heberle, H., \& Zonta, G. M. F. (2011). Electrical conductivity test for mung beans seeds. Revista Brasileira de Sementes, 33(1), 123-130. https://doi.org/10.1590/S0101-31222011000100014

Barnett, H. L., \& Hunter, B. B. (1999). Illustrated Genera of Imperfect Fungi. $4^{\text {th }}$ Edition. American Phytopathology Society: Minnesota, 218 p.

Binotti, F. F. S., Arf, O., Sá, M. E., Buzetti, S., Alvarez, A. C. C., \& Kamimura, K. M. (2009). Effect of sources, doses and nitrogen split in winter common bean in no tillage system. Bragantia, 68(2), 473-481. https://doi.org/10.1590/S0006-87052009000200022

Brasil. (2009a). Ministério da Agricultura, Pecuária e Abastecimento - MAPA. Manual de Análise Sanitária de Sementes. MAPA: Brasília, 200p.

Brasil. (2009b). Ministério da Agricultura, Pecuária e Abastecimento. Regras para Análise de Sementes. MAPA: Brasília, 395p.

Brasil. (2013). Ministério da Agricultura, Pecuária e Abastecimento. Instrução Normativa $\mathrm{N}^{\circ}$ 45 de 17 de setembro de 2013: Padrões para produção e comercialização de sementes de soja. Anexo XXIII. Normative Instruction No. 45 of September 17 ${ }^{\text {th }}$, 2013: Standards for soybean seed production and marketing. Annex XXIII. [Online] Available: http://www.agricultura.gov.br/assuntos/insumos-agropecuarios/insumos-agricolas/sementes-e -mudas/publicacoes-sementes-e-mudas/copy_of_INN45de17desetembrode2013.pdf (June 6, 2019). 
Cameron, J. C., Lehman, R. M., Sexton, P., Osborne, S. L., \& Taheri, W. I. (2017). Fungicidal Seed Coatings Exert Minor Effects on Arbuscular Mycorrhizal Fungi and Plant Nutrient Content. Agronomy Journal, 109(3), 1005-1012. https://doi.org/10.2134/agronj2016.10.0597

Canbolat, M., Bilen, S., Çakmakçi, R., Sahin, F., \& Aydi, A. (2006). Effect of plant growth-promoting bacteria and soil compaction on barley seeding growth, nutrient uptake soil properties and rhizosphere microflora. Biology and Fertility of Soils, 42(4), 350-357. https://doi.org/10.1007/s00374-005-0034-9

Carvalho, D. D. C., Mello, S. C. M., Lobo Júnior, M., \& Silva M. C. (2011). Control of Fusarium oxysporum f. sp phaseoli in vitro and on seeds and growth promotion of common bean in early stages by Trichoderma harzianum. Tropical Plant Pathology, 36(1), 28-34. https://doi.org/10.1590/S1982-56762011000100004

Chowdappa, P., Mohan, K.S.P., Lakshmi, M.J., \& Upreti, K.K. (2013). Growth stimulation and induction of systemic resistance in tomato against early and late blight by Bacillus subtilis OTPB1 or Trichoderma harzianum OTPB3. Biological Control, 65(1), 109-117. https://doi.org/10.1016/j.biocontrol.2012.11.009

Conab. (2019) Companhia Nacional de Abastecimento. Acompanhamento da Safra Brasileira de Grãos. Crop 2018/2019 - Oitavo Levantamento. [Online] Available: http://www.conab.gov.br/info-agro/safras/graos/boletim-da-safra-de-graos. (May 30 ${ }^{\text {th }}$, 2019).

Coutinho, W. M., Machado, J. C., Vieira, M. C. V., Guimarães, R. M., \& Ferreira, D. F. (2001). Uso da restrição hídrica na inibição ou retardamento da germinação de sementes de arroz e feijão submetidas ao teste de sanidade em meio ágar-água. Revista Brasileira Sementes, 23(2), 127-135. https://doi.org/10.17801/0101-3122/rbs.v23n2p127-135

Cruciol, G. C. D., \& Costa, M. L. N. (2017). Influence of Macrophomina phaseolina inoculation methodologies on the performance of soybean cultivars. Summa Phytopathologica, 44(1), 32-37. https://doi.org/10.1590/0100-5405/2185

Dutra, A. S., Bezerra, F. T. C., Nascimento, P. R., \& Lima, D. C. (2012). Yield and seed quality of cowpea as a function of nitrogen fertilization. Revista Ciência Agronômica, 43(4), 816-821. https://doi.org/10.1590/S1806-66902012000400025

El-Gremi, S. M., Draz, I. S., \& Youssef, W. A. E. (2017). Biological control of pathogens associated with kernel black point disease of wheat. Crop Protection, 91, 13-19. https://doi.org/10.1016/j.cropro.2016.08.034

Ferreira, D. F. (2011). Sisvar: a computer statistical analysis system. Ciência \& Agrotecnologia, 35(6), 1039-1042. https://doi.org/10.1590/S1413-70542011000600001

Figueirêdo, G. S., Figueirêdo, L. C., Cavalcanti, F. C. N., Santos, A. C., Costa, A. F., \& Oliveira, N. T. (2010). Biological and chemical control of Sclerotinia sclerotiorum using Trichoderma spp. and Ulocladium atrum and pathogenicity to bean plants. Brazilian Archives of Biology and Technology, 53(1), 1-9. https://doi.org/10.1590/S1516-89132010000100001 
Galon, L., Forte, C. T., Gabiatti, R. L., Radunz, L. L., Aspiazú, I., Kujawinski, R., ... Rossetti, J. (2016). Interference and economic threshold level for control of beggartick on bean cultivars. Planta Daninha, 34(3), 411-422. https://doi.org/10.1590/s0100-83582016340300002

Guiscem, J. M., Farias, A. S., Figueiredo, T. R., Chaves, S. M. A., Figueiredo, T. B., Pereira, C. F., ... Martins, M. R. (2010). Evaluation of the cowpea seeds vigour through of the cold test and accelerated aging test. Revista de Ciências Agrárias (Lisboa), 33(2), 182-191.

Harman, G. E. (2006). Overview of mechanisms and uses of Trichoderma spp. Phytopathology, 96(2), 190-194. https://doi.org/10.1094/PHYTO-96-0190

Kipngeno, P., Losenge, T., Maina, N., Kahangi, E., \& Juma, P. (2015). Efficacy of Bacillus subtilis and Trichoderma asperellum against Pythium aphanidermatum in tomatoes. Biological Control, 90, 92-95. https://doi.org/10.1016/j.biocontrol.2015.05.017

Lehner, M. S., Del Ponte, E. M., Gugino, B. K., Kikkert, J. R., \& Pethybridge, S. J. (2017). Sensitivity and efficacy of boscalid, fluazinam, and thiophanate-methyl for white mold in snap bean in New York. Plant Disease, 101(7), 1253-1258. https://doi.org/10.1094/PDIS-12-16-1731-RE

Machado, J. C. (2000). Seed treatment in disease control. UFLA/FAEPE: Lavras, 128 p.

Maguire, J. D. (1962). Speed of germination-aid in selection and evaluation for seedling $\begin{array}{llll}\text { emerge and } \quad \text { vigor. } & \text { Crop } & \text { Science, } & \text { 2(11), }\end{array}$ https://doi.org/10.2135/cropsci1962.0011183X000200020033x

Marcos Filho, J. (1999). Vigor tests: importance and use. In Krzyzanowski, F.C., Vieira, R.D., França Neto, J.B. (Eds.), Seed Vigor: Concepts and Tests (pp. 1-21). Londrina: ABRATES.

Martínez-Medina, A., Pascual, J. A., Alfocea, F. P., Albacete, A., \& Roldán, A. (2010). Trichoderma harzianum and Glomus intraradices modify the hormone disruption induced by Fusarium oxysporum infection in melon plants. Phytopathology, 100(7), 682-688. https://doi.org/10.1094/PHYTO-100-7-0682

Migliorini, P., Dorneles, R. K., Rodrigues, F. G., Paula, G., \& Tunes M. V. L. (2017). Inoculation methods of Colletotrichum lindemuthianum in seeds of Phaseolus vulgaris. Biotemas, 30(1), 37-43. https://doi.org/10.5007/2175-7925.2017v30n1p37

Migliorini, P., Milanesi, P. M., Mezzomo, R., Maciel, C. G., \& Muniz M. F. B. (2018). Fusarium solani and $F$. oxysporum: etiological agents of damping off in crambe. Revista Brasileira de Ciências Agrárias, 13(1), e5510. https://doi.org/10.5039/agraria.v13i1a5510

Miguel, M. H., \& Cicero, S. M. (1999). Cold test for bean seed vigor evaluation. Scientia Agricola, 56(4), 1233-1243. https://doi.org/10.1590/S0103-90161999000500027

Moura, A. B., Santos, A. G., Farias, C. R. J., Ludwig, J., Corrêa, B. O., \& Soares, V. N. (2018). Combination of biocontrol bacteria for rice seeds microbiolization: incidence and transmission of Bipolaris oryzae, and plant growth. Journal of Seed Science, 40(4), 378-387. https://doi.org/10.1590/2317-1545v40n4192970 
Mycobank. (2019). Sclerotinia sclerotiorum. [Online] Available: http://www.mycobank.org/BioloMICSDetails.aspx?Rec=24988. (May 15 ${ }^{\text {th }}$, 2019).

Pedroso, D. C., Menezes, V. O., Muniz, M. F. B., Piveta, G., Tunes, L. M., Muller, J., \& Menezes, N. L. (2010). Inoculation methods of Alternaria alternata and A. dauci in parsley seeds and their influence on the physiological quality. Revista Brasileira de Sementes, 32(3), 79-85. https://doi.org/10.1590/S0101-31222010000300009

Pereira, C. E., Oliveira, J. A., Rosa, M. C. M., Oliveira, G. E., \& Costa Neto, J. (2009). Fungicide treatment of soybean seeds inoculated with Colletotrichum truncatum. Ciência Rural, 39(9), 2390-2395. https://doi.org/10.1590/S0103-84782009005000215

Rey, M. S., Santos, J. D., \& Pierobom, C. R. (2009). Colletotrichum lindemuthianum seed-plant transmission in beans. Arquivos do Instituto Biológico, 76(3), 465-470.

Rocha, F. S., Catão, H. C. R. M., Brandão, A. A., \& Gomes, L. A. A. (2014). Damage caused by different inoculum levels of Aspergillus ochraceus on the vigour of soybean seeds. Semina: Ciências Agrárias, 35(6), 2895-2904. https://doi.org/10.5433/1679-0359.2014v35n6p2895

Silva, F. F., Castro, E. M., Moreira, S. I., Ferreira, T. C., Lima, A. E., \& Alves, E. (2017). Emergence and ultrastructural analysis of soybean seedlings inoculated with Sclerotinia sclerotiorum under the effect of Trichoderma harzianum application. Summa Phytopathologica, 43(1), 41-45. https://doi.org/10.1590/0100-5405/2212

Singh, A., Shahid, M., Srivastava, M., Pandey, S., Sharma, A., \& Kumar, V. (2014). Optimal physical parameters for growth of Trichoderma species at varying $\mathrm{pH}$, temperature and agitation. Virology \& Mycology, 3, 3-10. https://doi.org/10.4172/2161-0517.1000127

Singh, U. B., Malviya, D., Singh, S., Kumar, M., Sahu, P. K., Singh, H. V., ... Saxena A. K. (2019). Trichoderma harzianum and methyl jasmonate-induced resistance to Bipolaris sorokiniana through enhanced phenylpropanoid ctivities in bread wheat (Triticum aestivum L.). Frontiers in Microbiology, 10, 1697. https://doi.org/10.3389/fmicb.2019.01697

Smaniotto, T. A. S., Resende, O., Marçal, K. A. F., Oliveira, D. E. C., \& Simon, G. A. (2014). Physiological quality of soybean seeds stored in different conditions. Revista Brasileira de Engenharia Agrícola e Ambiental, 18(4), 446-453. https://doi.org/10.1590/S1415-43662014000400013

Sumida, C. H., Canteri, M. G., Peit, D. C., Tibolla, F., Orsini, I. P., Araújo, F. A., Chagas, D. F., \& Calvos, N. S. (2015). Chemical and biological control of Sclerotinia stem rot in the soybean crop. Ciência Rural, 45(5), 760-766. https://doi.org/10.1590/0103-8478cr20140198

Tonello, E. S., Fabbian, N. L., Sacon, D., Netto, A., Silva, V. N., \& Milanesi, P. M. (2019). Soybean seed origin effects on physiological and sanitary quality and crop yield. Semina. Ciências Agrárias, 40(5), 1789-1804. https://doi.org/10.5433/1679-0359.2019v40n5p1789

Urrea, K., Rupe, J. C., \& Rothrock, C. S. (2013). Effect of fungicide seed treatments, cultivars, and soils on soybean stand establishment. Plant Disease, 97, 807-812. https://doi.org/10.1094/PDIS-08-12-0772-RE 
Venturoso, L. R., Bacchi, L., Gavassoni, W. L., \& Venturoso, L. A. C. (2015). Inoculação de Sclerotinia sclerotiorum em sementes de oleaginosas: transmissão e seus efeitos sobre a $\begin{array}{llll}\text { emergência de } \text { plantas. } & \text { 7êencia } & \text { Rural, } & \text { 45(5), }\end{array}$ https://doi.org/10.1590/0103-8478cr20140374

Vieira, B. G. T. L., Vieira, R. D., Krzyzanowski, F. C., \& Neto, J. B. F. (2010). Alternative procedure for the cold test for soybean seeds. Scientia Agricola, 67(5), 540-545. https://doi.org/10.1590/S0103-90162010000500007

Wang, H., Shi, Y., Wang, D., Yao, Z., Wang, Y., Liu, J., Zhang, S., \& Wang, A. (2018). A Biocontrol strain of Bacillus subtilis WXCDD105 used to control tomato Botrytis cinerea and Cladosporium fulvum Cooke and promote the growth of seedlings. International Journal of Molecular Sciences, 19(5), e1371. https://doi.org/10.3390/ijms19051371

Wendland, A., Moreira, A. S., Bianchini, A., Giampan, J. S., \& Lobo Jr., M. (2016). Doenças do feijoeiro. In Amorim, L., Rezende, J.A.M., Bergamin Filho, A., \& Camargo, L.E.A. (Eds.), Manual de Fitopatologia: doenças das plantas cultivadas (pp. 383-396). Ouro Fino: Agronômica Ceres.

Wu, B. M., \& Subbarao, K. V. (2008). Effects of soil temperature, moisture, and burial depths on carpogenic germination of Sclerotinia sclerotiorum and S. minor. Phytopathology, 98(10), 1144-1152. https://doi.org/10.1094/PHYTO-98-10-1144

Xu, M. X., Jeffries, P., Pautasso, M., \& Jeger, M. J. (2011). Combined use of biocontrol agentes to manage plant diseases in theory and practice. Phytopathology, 101(9), 1024-1031. https://doi.org/10.1094/PHYTO-08-10-0216

Zhang, F., Ge, H., Zhang, F., Guo, N., Wang, Y., Chen, L., Ji, X., \& Li, C. (2016). Biocontrol potential of Trichoderma harzianum, isolate T-aloe against Sclerotinia sclerotiorum in soybean. Plant Physiology and Biochemistry, 100, 64-74. https://doi.org/10.1016/j.plaphy.2015.12.017

Zhang, K., He, Y., Chen, C., \& Ji, X. (2017). Trichoderma harzianum containing 1-aminocyclopropane-1-carboxylate deaminase and chitinase improved growth and diminished adverse effect caused by Fusarium oxysporum in soybean. Journal of Plant Physiology, 10, 84-94. https://doi.org/10.1016/j.jplph.2016.10.012

Zucareli, C., Brzezinski, C. R., Abati, J., Werner, F., Ramos, E. U., \& Nakagawa, J. (2015). Physiologic quality of carioca bean seeds stored in different environments. Revista Brasileira de Engenharia Agrícola e Ambiental, 19(8), 803-809. https://doi.org/10.1590/1807-1929/agriambi.v19n8p803-809

\section{Copyright Disclaimer}

Copyright for this article is retained by the author(s), with first publication rights granted to the journal.

This is an open-access article distributed under the terms and conditions of the Creative Commons Attribution license (http://creativecommons.org/licenses/by/4.0/). 